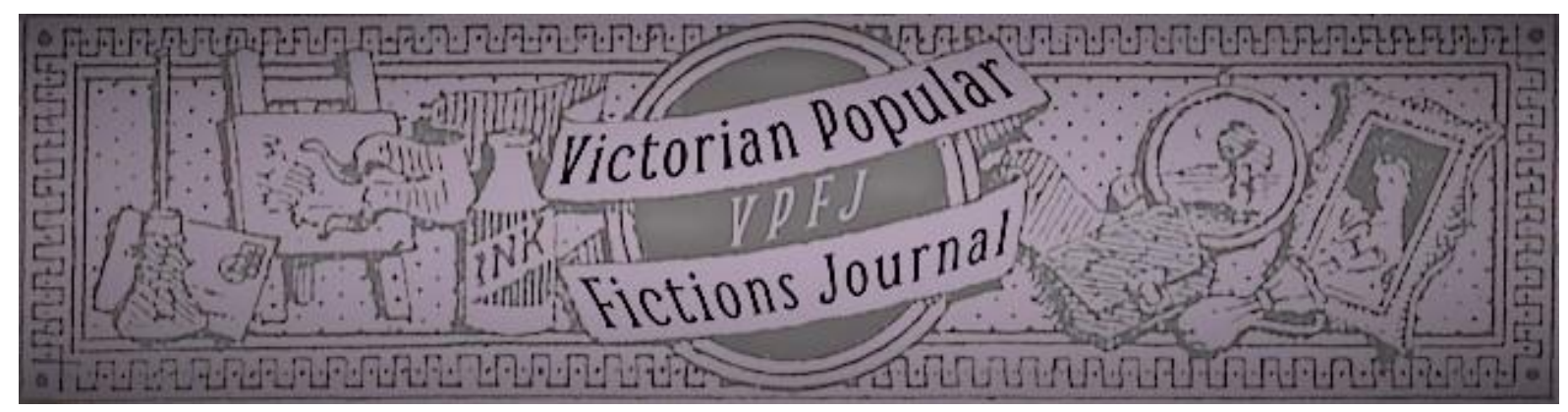

\title{
Darkest Wessex: Hardy, the Gothic Short Story, and Masculinity
}

\author{
Tracy Hayes
}

\begin{abstract}
Thomas Hardy is generally recognised as a powerful delineator of the female psyche, his intuitive understanding of the emotional complexities of women such as Tess Durbeyfield and Sue Bridehead being emphasised at the expense of his male characters, who are often viewed as weak and twodimensional. However, Hardy's men are also examined in depth, in light of their ambitions, sensitivities, hypocrisies and social expectations, thereby giving voice to discursive categories of maleness often elided in the work of his contemporaries. In the Gothic short story as featured in Blackwood's and similar magazines, the author's intention is to elicit terror within a circumscribed textual space, creating a balance between actuality and artifice which holds the reader enthralled. The effect is achieved through the power of brevity. In this context a withered arm, a luridly disfigured statue and a demonic fiddle player are used as vehicles by Hardy through which the incredible or fantastic highlight instances of toxic masculinity and grotesque extremes of human nature in a concentrated modality which leaves behind an indelible impression.
\end{abstract}

\section{Key Words}

Thomas Hardy; Gothic; masculinity; short story; periodicals; folklore.

Date of Acceptance: 1 October 2020

Date of Publication: 25 October 2020

Double Blind Peer Reviewed

\section{Recommended Citation}

Hayes, Tracy. 2020. "Darkest Wessex: Hardy, the Gothic Short Story, and Masculinity." Victorian Popular Fictions 2.2: 76-94.

ISSN: 2632-4253 (online).

DOI: https://doi.org/10.46911/NBIQ9295 


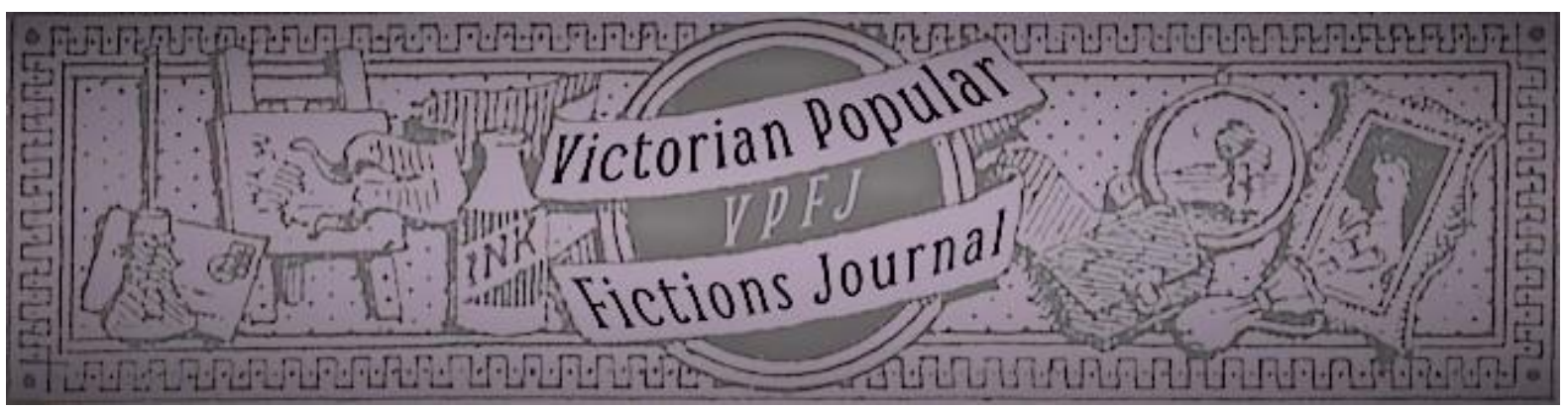

\title{
Darkest Wessex: Hardy, the Gothic Short Story, and Masculinity
}

\author{
Tracy Hayes
}

\section{Introduction}

In a number of his short stories Thomas Hardy adopted the themes and signifiers of Gothic in order to explore social and psycho-sexual constructions of Victorian masculinity. Ideas of masculinity and manliness are far from stable or fixed, and, as such, "masculinity" cannot be considered as a monolithic hetero-normative construct. Masculinity is perhaps better understood in terms of specific historical junctures, where definitions of what constituted "manliness" can vary wildly even within the span of the Victorian period. Stephen Whitehead has pointed out that "gender structures are neither permanent nor immune from subversion," the sheer "multiplicity of masculinities" amounting to "countless ways of men expressing their manliness across different times, places and contexts" (2002: 97). Hardy is generally recognized as an excellent delineator of the female, his intuitive understanding of the psychological complexities of women such as Tess Durbeyfield and Sue Bridehead being emphasized at the expense of his male characters who are often viewed as weak and twodimensional. ${ }^{1}$ What is less frequently recognized is that Hardy often also examines men in light of their ambitions, sensitivities, hypocrisies and social expectations, thereby giving voice to discursive categories of maleness often elided in the work of his contemporaries. Where novel-writing provides the opportunity for extended use of techniques such as agon,

\footnotetext{
${ }^{1}$ Judith Mitchell points out that apart from Michael Henchard and Jude Fawley, "Hardy's male characters have been largely ignored" (2010: 301). Two characterisations singled out for particular opprobrium by critics seem to be Alec Durberville and Richard Phillotson. In 1914, D.H. Lawrence wrote of Alec as being "a non-individual," and described Phillotson as "a function-fulfilling organ" with "no separate existence," incapable of creating "a single new movement or thought or expression" ([1914] 1998: 45, 64). A more recent example is from Simon Gatrell who reads Alec Durberville as "a cardboard cutout" and "two-dimensional" (1993: 106). Susan Hill in her introduction to the short story collection, The Distracted Preacher and Other Tales, also comments on Hardy's male characters as being perceived as "weak and two-dimensional, existing in the shadow of the women in whom the writer was really interested" (1979: 15).
} 
anagnorisis and perpeteia with regards to character development and plot - such as Hardy's representations of the complex and volatile relationships between Henchard and Farfrae in The Mayor of Casterbridge (1886), or Stephen and Knight in A Pair of Blue Eyes (1873) the short story form requires a specific incident or character trait to create an immediate and lasting impact within a constrained word limit. ${ }^{2}$ As Tim Killick notes, a tale, as opposed to a novel, is able to be read in a single sitting, and can thus "hold complete sway over the reader for the duration" (2008: 7). The term "tale" also has roots in a specifically oral tradition, comprising folktales, ballads, exemplars and fables; and lends itself to a form of story-telling in which the sensational and melodramatic, horrific and terrifying can all be rendered with a degree of verisimilitude disguised as historical fact. According to Graham Law, a tale generates "its own aesthetic norms," mimicking a mode of oral delivery "while combining a distinctly Gothic fear of the uncanny with the consolations of hearth and home" (2017: 14). With differences in genre producing specific reader expectations, the Gothic short story allows for specific incidents or character traits of a more extreme nature to be related, whilst still retaining reader credulity. When receiving a story in the mode of a folktale, instances of the marvellous are presented as actuality and accepted by the reader in kind; this is in contrast with the realist novel in which incidents such as "turning of the blood" will jar assumptions of probability. Killick refers to Edgar Allan Poe's theory of "the unity of effect," in which "no word or sentence should be included" that does not further the author's intentions in bringing about the exact response wished for in the prospective reader (2008: 7). The Gothic as a genre exploits readerly expectations of lurid actions perpetrated by grotesque characters as part of convoluted plots involving issues of primogeniture and inheritance. The Gothic short story as featured in Blackwood's and similar magazines is more dependent upon a "unity of effect" in which no word is superfluous, the author's intention being to elicit terror within a limited textual space, creating a balance between actuality and artifice which holds the reader enthralled. The effect is achieved through the power of brevity. As will be shown below, a withered arm, a disfigured statue and a demonic fiddle player are used as vehicles by Hardy through which the incredible or fantastic highlight instances of toxic masculinity and grotesque extremes of human nature. This essay will illustrate how Hardy's short stories differ from his novels in narrative structure, how certain delineations of Victorian masculinity are delivered within a format constrained by periodical and audience expectations, and how by adopting Gothic tropes Hardy engaged with and extended discussions of a traditionally heavily gendered genre of fiction.

While Hardy's fame and posthumous reputation generally rests on novels such as Far From the Madding Crowd (1874), Tess of the d'Urbervilles (1891) and Jude the Obscure (1895), he in fact wrote forty-nine short stories collected in four volumes: Wessex Tales (1888), A Group of Noble Dames (1891), Life's Little Ironies (1894), and A Changed Man and Other Tales (1913). His novels often attract criticism for their convoluted plots, archaisms, coincidences and randomly placed learned references, but his short stories are eminently readable. Hardy's short story writing was usually the result of a direct request from magazine editors, and was undertaken for financial remuneration - factors which led many readers, both Victorian and modern, to view these tales as mere pot-boilers. However, as Sophie Gilmartin and Rod Mengham note, the act of writing short stories for publication called for "a constant readjustment of his [Hardy's] sense of the audience he was writing for,

\footnotetext{
${ }^{2}$ Agon refers to the contest or dispute between two characters which forms a major part of the action within a text. Anagnorisis is the Greek word for recognition, or discovery, denoting a turning point in which the main protagonist recognises the true state of affairs, having previously been in ignorance. Peripeteia is a plot device in which a sudden reversal of a character's circumstances or fortunes takes place, usually involving the ultimate downfall of the protagonist.
} 
a chameleon-like adaptability to different sets of expectations and criteria of acceptability" (2016: 106). In most cases Hardy seems to have been willing to tailor his stories to the social character or particular readership of a periodical's audience (Law 2017: 15). Peter Widdowson points out that short story writing was an onerous task: Hardy "would have had to register the particular identities of the magazines he was writing for on both sides of the Atlantic and their target readerships" (2013: 368). Hardy sent letters to various periodical publishers stating his aim to use his "best efforts to please your numerous readers," maintaining "a healthy tone, suitable to intelligent youth of both sexes" (Purdy and Millgate 1978: 116). This made rejections by periodicals such as The Graphic for tales that a "father" may not feel comfortable "reading in family-circles" all the more perplexing (Millgate 2004: 281). The stories originally published in The Graphic as a cycle called "A Group of Noble Dames" and which contained "Barbara of the House of Grebe" (1890) were particularly butchered in order to meet editorial demands. Following an interview at the offices of The Graphic, Hardy wrote "Here's a pretty job! Must smooth these directors somehow I suppose" (Purdy and Millgate 1978: 227). The demands in this particular case were "no mention or hint of pregnancy, childbirth, nor sexual relations, whether adulterous or sanctioned by marriage, one or another of which offending incidents occurred in all six tales" (Brownson 2007: 7). As will be shown below, much egregious bowdlerisation was carried out, on "Barbara" in particular, and Widdowson notes that Hardy "had intended from the start to reinstate the original material once he had earned his money in the market place" (2013: 374). Law observes that "Barbara" in particular was singled out as "a hideous hateful fantasy" (2017: 12), and it is worth mentioning here that what we now term "Gothic" tales were originally referred to by publishers and readers as "romances" or "fantasies," which has ensured the generic categorisation of this story from the moment of first publication.

In his short stories Hardy studied the perverseness of human nature in both romantic and sexual matters, often pursuing them to bitter and violent conclusions. Where the prevailing sexual double standards of the nineteenth century are exposed in a protracted dénouement of two to three chapters in his novel Tess of the d'Urbervilles, in the tale "The Withered Arm" (1888) discussed below, the constraints of the short story format mean that the dénouement takes place within the space of a few lines, making Hardy's interrogation of masculine sexual mores all the more powerful for its immediacy. Similarly, the climax of "The Fiddler of the Reels" (1893) comprises only a handful of paragraphs, containing a damning indictment of popularly received notions regarding maternal duties. Having his interrogations of sexual mores and the corresponding societal hypocrisies so heavily deleted while in magazine publications, such as was the fate with the short story cycle "A Group of Noble Dames," confirmed for Hardy a disdain of periodical editors and readers, who, as Brownson notes, Hardy divided into "the Grundyist and subscriber," and the "mature and penetrating reader," with the first category seemingly the most prevalent (Brownson 2007: 8). This may have led to his writing "Candour in English Fiction" (1890) in which Hardy stated that the author "must either whip and scourge characters into doing something contrary to their natures, to produce the spurious effect of their being in harmony with social forms and ordinances, or, by leaving them alone to act as they will, he must bring down the thunders of respectability upon his head, not to say ruin his editor, his publisher, and himself" (Hardy, quoted in Orel 1969: 130). Richard Nemesvari comments that Hardy's fiction is "eclectic, containing elements of the realist, the tragic, the sensational, the pastoral, the Gothic, the melodramatic, and the didactic," he has created "a whirl of generic hybridity that destabilizes reader response by refusing any firm position from which to develop a secure interpretive stance" (2013: 102). But while Nemesvari here is referring to the novels, the observation is equally true of Hardy's short stories. Hardy did not believe that a fiction writer's role was simply to serve up a slice of mundane everyday life, hence his utilisation of unusual 
characters and plots, and instances of wild improbability within his shorter narratives that in essence crystallise and intensify a particular idea, which would prove difficult to sustain throughout a lengthier text. In his autobiography, published under his second wife's name, he stated that "A story must be exceptional enough to justify its telling" (Millgate 1984: 268). Hardy's Gothic short stories are indeed exceptional in their brief and brutal depictions of toxic masculinity and psychological torture.

Brigitte Hervoche-Bertho notes that Hardy's "diffusion of Gothic motifs and taste for macabre folktales" provides a fruitful platform from which to explore themes such as gender and social conventions through an alternative lens which may be used to confront sexual taboos, and highlight what was previously hidden (2001: 451). Through the Gothic short story mode, Hardy is able to provide much more concentrated instances of the bizarre and improbable than he can in his novels. His striking and often unusual characters, such as his cunning folk and devilish musicians, leave an impression all the stronger for the brevity of their appearance. James Scott writes of Hardy as having gleaned from the Gothic tradition "certain devices conducive to spectacular terror" (1963: 365). Scott identifies three elements within Hardy's shorter fiction which readily identify him with the Gothic - "the preternatural, the terrible, and the grotesque" (370), each of which permeates the dark tales forming the focus of this essay. But Hardy also confronts sexual and societal taboos in his manipulation of the Gothic genre as bifurcated into "male" and "female" traditions. Angela Wright notes that while the Gothic challenges contemporary assumptions about gender, it is also overly simplistic to argue for "a continuous Female Gothic tradition" as promulgated by the literary critic Ellen Moers with reference to the novels of Ann Radcliffe (Wright 2007: 129). By the same token, the notion of Male Gothic is likewise unable to be reduced to a single essentialist definition. Gothic stories were written by both male and female authors with myriad variations, and consumed by both male and female readers "with a seemingly unappeasable appetite" (Clery 1995: 203). While Ann Radcliffe's novels were dominated by persecuted but courageous young heroines, and male-authored novels such as Matthew Lewis's The Monk (1796) and William Beckford's Vathek (1786) revolved around lurid villains performing sordid acts, this dichotomy was challenged as early as Charlotte Dacre's sensationalist Zofloya (1806), a novel in which, as Wright points out, "Dacre was proud to acknowledge that she participated in the same tradition" as Lewis, whose work had been critically reviled (2007: 147). Zofloya features a female character who willingly offers her soul to the Devil in the form of a Moor in exchange for her immoral fantasies becoming realities. Therefore we "cannot presume any straightforward female Gothic as a continuous and coherent category" (147). Nor can we reduce the Male Gothic to a simplistic essentialist category. Hardy contributes to this debate through his Gothic tales in which Victorian conventions of gender are blurred, both with regards to physical appearance and societal expectations, and in which elements of both "Male" and "Female" Gothic are in evidence.

In "The Withered Arm" (1888), Hardy represents an instance of esoteric masculinity in the person of Conjuror Trendle, whose eccentricities are not derided but revered due to his lack of ostentation and his refusal to take monetary payment for his services. And while his character is male and representative of the more fantastical elements within the story, his benevolence serves to emphasise the contrasting malevolence of Farmer Lodge, whose depiction is otherwise that of the realist school of fiction. "Barbara of the House of Grebe" (1890) is arguably Hardy's most Gothic short story, exploring the dark recesses of psychosexuality and how a sociopathic male causes a massive psychological schism in his wife. However the true victim of this story is not the terrorised naïve heroine, but the young Edmond Willowes, a male casualty of society's obsession with aesthetic appearance. "The Fiddler of the Reels" (1893), one of Hardy's most critically discussed short stories, articulates 
a male form of "Othering" in which a man who is not provided with a single word of dialogue, yet dominates the narrative, exploits music and dance as forms of physical and mental torture. But as with "Barbara," the reversal of Victorian conventions of gender - in this case the refutation of maternal instinct - serves to undermine Radcliffean notions of the persecuted female.

These three stories also represent examples of toxic masculinity: male protagonists who glory in the manipulation and domination of their female counterparts as a traditional aspect of Victorian patriarchy, ultimately resulting in the fracturing of their female partners' psyches. The portrayal of Lord Uplandtowers in "Barbara of the House of Grebe" is particularly disturbing in that the psychological poisoning of his wife produces a lobotomising effect upon Barbara, engendering a sense of revulsion in the reader which is enhanced by the utilisation of tropes such as imprisonment and disfigurement. In "The Fiddler of the Reels," a maternally nurturing man is pitted against a male character whose physical beauty is almost feminine in its features, but whose effect upon the female inhabitants of the village he resides near is universally ruinous. However it is Hardy's earlier story, "The Withered Arm," which best embodies the Gothic elements of the preternatural, the terrible, and the grotesque, as identified by Scott. Here a cunning-man unwittingly causes the death of a beleaguered woman seeking a grotesque remedy for what she perceives as her failure to retain the affection of a toxic man. ${ }^{3}$

\section{Toxic and Esoteric Masculinity in "The Withered Arm"}

"The Withered Arm" (1888), submitted to Blackwood's Magazine in January 1888, contains examples of the intersection between Victorian science and folklore along with elements of the preternatural. Indeed Gothic tropes of hanging and disfigurement serve to validate the folkloristic elements such as oomancy and corpse-curing, which would otherwise have been marginalised by both magazine editors and readers for being too fantastical, though as Martin Ray points out, "Longman's Magazine rejected it as being too grim and unrelieved for a magazine read mostly by girls" (1997: 35). Engaging with myth and the occult, most notably in the hag-riding episode, this story incorporates symbolism and the esoteric in order to explore a liminal yet benevolent construction of masculinity alongside a more poisonous one. One of Hardy's most gripping stories, it is a tale steeped in Wessex superstitions and legends, while also serving to castigate patriarchal conventions such as primogeniture. Farmer Lodge brings home a pretty new young wife called Gertrude, much to the consternation of Rhoda Brook, a washed out milk-maid who we soon discover gave birth to Lodge's illegitimate son some years before. Rhoda has a dream in which she seems to be "hag-ridden" by an older withered version of Gertrude, who perches on her chest, almost suffocating her. In a panic Rhoda lashes out, grabbing Gertrude's arm and flinging her to the floor. The next day mysterious finger print marks appear on young Gertrude's left arm, which slowly begins to wither.

Jacqueline Dillion posits that the majority of recent readings of the story have adopted Freudian or Jungian perspectives focussing on the supposed sexual jealousy between Gertrude and Rhoda - "Hardy's ability to drive the psychological elements of the story naturally warrants such readings" - but she rightly warns about the "issues with approaching

\footnotetext{
${ }^{3}$ As the term "toxic masculinity" is largely a twenty-first century mode of reference within public discourses of the 2010s, for the purposes of this essay it is applied with regards to the glorification of male strength, virility and dominance to the detriment of the female protagonist's mental health. Hardy can be seen as anticipating and interrogating this psychological construct through his critical scrutiny of Victorian patriarchal hetero-normativity.
} 
the story too symbolically" (2016: 57). Hag-riding, or "overlooking," is a form of witchcraft in which someone exerts an evil influence in order to do an injury to another person or animal, and was a popular belief in Dorset folklore (Udal 1922: 204-5). One of the first of Hardy's Wessex topographers, Hermann Lea, writes that

The story brings before us vividly one of the old-time superstitions which are now fast dying out. The dream which came to Rhoda is an incident by no means uncommon, and similar occurrences have been repeatedly brought before the writer of this Guide. By a certain class of people it would perhaps be referred to as a nightmare; amongst the less literate such a dreamer would describe herself as being "hag-rod" [...] doubtless the recorded instances would be much more common, were it not that the sufferers are chary of mentioning the facts, save to those who will be more likely to show sympathy than scepticism.

(Lea [1913] 1969: 150)

Gilmartin and Mengham read the act simply as "the spurned Rhoda Brook 'overlook[ing]' her rival" (2016: 5), and Hardy's third person narrator refers to it as "an act of malignity" (Hardy [1888] 1979: 145). But the nature of this particular instance of hag-riding is more ambiguous than these judgements suggest: in the dream it is actually Gertrude astride Rhoda's chest, and thus she would appear to be the hag-rider, and yet it is Gertrude who suffers from the physical defect which follows. And indeed, neither woman wishes the other ill, but by the conclusion of the tale they have both been punished for the sins of a man, Farmer Lodge. Elsewhere, Gilmartin relates how Leslie Stephen, a mentor of Hardy's, advised the author to "provide a scientific explanation for the urban readership of his supernatural story," and how Hardy rejected this advice, leaving the "overlooking" and "withering" unexplained, refusing to "mitigate the sense of evil with a rational explanation" and thus lending the tale a much more disturbing atmosphere (2013: 138).

The naïve Gertrude seeks "nostrums and charms," "mystic herbs" and "books of necromancy" (Hardy [1888] 1979: 151) in order to find a cure for the "withering," a disfigurement that has estranged her superficial husband, he having only courted her for her "grace and beauty" and the possibility of bearing a legitimate son (150). Rumours circulate amongst the small community of Holmstoke that the loss of the use of Gertrude's arm "was owing to her being 'overlooked' by Rhoda Brook" (150), though it was actually Rhoda who was "ridden" by "the incubus" (150). Thus Rhoda suffers the ignominy of "falling" twice by bearing an illegitimate son, and by being alluded to as a witch. Kristin Brady tellingly comments on Rhoda's interest in Gertrude's social standing, pointing to the older woman's preoccupation with the younger's "hands, dress, and manners," which "serves to sharpen the differences between the two women and to underline their opposing physical, social, and moral attributes" (1982: 25). Brady identifies further dichotomies between the two women such as their being respectively dark and fair, "guiltily vengeful and innocently victimized" (25). But as stated above, the nature of the hag-riding episode is ambiguous at the very least, and it is far from clear either that Rhoda does feel vengeful towards Gertrude or that the distinction between the two women is as definitive as Brady suggests. Instead, Hardy leaves deliberately open the question of who is the cursed, and who the curser. Indeed, the two women are then brought together in commonality of purpose as they approach Conjuror Trendle in order to achieve a resolution to the dilemma of the "withering."

Trendle is "a solitary heathman," a "white wizard," a "cunning man" and "knowing man" (Hardy [1888] 1979: 151, 153, 158, 160). He is one of various "cunning folk" who appear in Hardy's fiction, such as Elizabeth Endorfield from Hardy's early novel Under the Greenwood Tree (1872), and Wide-oh from The Mayor of Casterbridge (1886). Wessex "cunning men" range in abilities and functions from the gifted amateur to strict professionals, 
and they are mediators between supernatural powers and the ordinary man. Practitioners of divination, folk-medicine, and magic, they may not be openly approved of and countenanced by the denizens of the communities in which they reside, but they are abided, and in some cases highly respected. Lea writes of passing the spot where Hardy based Trendle's cottage, where he inquired of a rustic working nearby "if he remembered it [the cottage] when occupied" (1969: 152). The gentleman replied in the affirmative, claiming that the occupant had been "a seventh of a seventh," the seventh son of a seventh son, "a strict essential for the holding of occult powers" (152). Ruth Firor notes that the apparatus and methods of these "knowing men" date from the "polemic of the Greek Hippolytus; the same paraphernalia and techniques appear in Reginald Scot's Discoverie of Witch-craft published in 1584" (Firor 1962: 86). Far from being malevolent, Trendle is represented by Hardy as benign, a man who practices magic for positive, curative ends. Not only does he not boast of his cabbalistic knowledge and talents, but he also downplays them as simply acts of chance. He has no interest in the personal business of the people who request his services, and refuses monetary payment. As opposed to the somewhat sociopathic and superficial Squire Lodge, who is obsessed with primogeniture and physical appearance, Trendle's masculinity is empathic - it is informed, or perhaps defined by, his personal practice of Einfühlung. Einfühlung translates from the German as "feeling into," a form of empathy that the German Romantic thinker Novalis viewed as a corrective against contemporary scientific attitudes of dissecting nature into its individual elements, such as Georges-Louis Leclerc's work on the mechanical properties of wood, or Carl Linnaeus's biological classification systems. Rather than promoting the many uses of wood and how its properties are of benefit to man, Einfühlung is an empathy with the wood itself - "feeling into" the originary tree as a like-minded creature. Not only do Hardy's literary notebooks mention Novalis in two specific entries (Björk 1985: $149,161)$, there is also a direct allusion to him in chapter 17 of The Mayor of Casterbridge: "Character is Fate, said Novalis" (Hardy [1886] 2004: 107). Trendle does not consider in what way each "customer" wishing to procure his services as a cunning man may be of use to him materially; instead he "feels into" these people, his empathy providing a natural corrective for what ails them spiritually. ${ }^{4}$

After performing the act of oomancy - breaking egg whites into a tumbler of water so that one may divine the face of the person who has caused them harm - Trendle informs Gertrude that she has been "blasted," and her wound may only be cured by "turning of the blood" (Hardy [1888] 1979: 154). She must touch with her withered arm the neck of a man who has just been hanged. ${ }^{5}$ Lea notes that in 1913 this was still considered an infallible cure by a number of "older Wessex folk" for "certain obscure diseases which defied medical diagnosis and treatment" (1969: 154), which supports Killick's contention that "tales" have their roots in a specifically oral tradition, particularly folklore. This may help the reader to understand Hardy's refusal of Leslie Stephen's direction to provide a scientific explanation of the "withering." Hardy is interested in the capacity of the tale as a form to draw upon its folkloric origins in order to suggest the possibility of a different relationship to nature and to other people than that provided by encroaching modernity. This idea returns below in the

\footnotetext{
${ }^{4}$ Indeed The Mayor of Casterbridge contains another of Hardy's "cunning men," Conjurer Fall, known by the citizens of Casterbridge as Wide-oh, consulted by the character Henchard for a weather prediction in an attempt by the latter at one-upmanship with his rival Farfrae.

${ }^{5}$ On "corpse-cures" Firor has this to say: "[they] take many revolting forms. On the basis of the magical efficacy of anything connected with the executed man, we find bits of hangmen's rope, pieces of the gibbet, gravestone chips, graveyard mold, pieces of the shroud, and even mock burials resorted to for cures for ailments ranging all the way from corns, warts, and headache to gout, epilepsy, goiter, and paralysis" (1962: 112).
} 
discussion of "The Fiddler of the Reels," a story in which Brady notes the co-presence of "folk and legendary elements with contemporary ways of explaining experience," which is what makes up the narrative's "essential method and complexity" (1982: 133). In "The Withered Arm," discourses of science and folklore intersect, just as they do later in "Fiddler," when Gertrude considers that blood-turning is "capable of a scientific no less than a ghastly interpretation" (Hardy [1888] 1979: 154), and galvanism is alluded to when it seems Gertrude is about to faint just before laying her cursed limb upon a hanged man's neck. Galvanism is also alluded to in "Fiddler" when simply the sound of Mop Ollamoor's footsteps passing outside the house is enough to make Car'line Aspent start from her chair as if she has suffered an electric shock. The dénouement of "The Withered Arm" reveals that the unfortunate victim of the gallows is the illegitimate son of Rhoda and Lodge, who both happen to witness Gertrude's attempt at corpse-curing as they come to collect the young man's body. In a rage, Rhoda once again grips Gertrude's arm and flings her away. Poor Gertrude dies of shock - "Her blood had been 'turned' indeed - too far" (163). Gertrude's preternaturally withered arm has led her to perform a desperate and grotesque act with terrible results. She is "turned" twice, just as Rhoda has "fallen twice." Both women suffer for their interactions with a destructive form of masculinity in the character of Farmer Lodge, the true villain of what Michael Millgate designates as one of Hardy's "most powerful - and most gruesome - shorter narratives" (2004: 266). Indeed through the mode of the Gothic short story, Hardy provides in this tale much more concentrated instances of the bizarre and improbable than he does in his novels, where the narrative scope allows for greater depth and detail. His "shorter narrative" is all the more "gruesome" for its contracted format.

According to Gilmartin and Mengham, Rhoda is "the agent of a malignant power" which serves to demonstrate the effects of guilt issues which arise "inevitably from the conditions of sexual rivalry which determine the relations of women under the gaze of men" (2016: 13). But while it may be true that the two women are initially positioned through Lodge's actions as rivals (his marriage to Gertrude closes down the possibility of him giving Rhoda or her son 'legitimacy'), in fact they go on to develop a close friendship that continues even after Conjurer Trendle's act of oomancy has clearly identified Rhoda as the person responsible for Gertrude's "blasting." The malignant power in this story is actually therefore embodied in Farmer Lodge, for not only has he married Gertrude simply for her physical beauty and potential provision of a male heir, but the reader is also reminded of his callous abandonment of Rhoda, and his refusal to publicly acknowledge their son. In the mode of the "female Gothic" as practised by Ann Radcliffe towards the end of the previous century, Hardy deploys Lodge as a vehicle for exploring female persecution, a manipulative male entrapping the heroine within the prison chamber of her disfigured arm. Her deformity having no perceivable tangible cause, Gertrude is entrapped by Lodge within a space of psychological torture based upon her supposed failed femininity, her "ugliness" prohibiting any physical allure and thus constituting a bar to the sexual congress which would result in an heir, and the fulfilment of her conjugal duties.

But where Radcliffe invested her tales with rational explanations for seemingly supernatural incidents, Hardy's introduction of elements of folklore means that this short story cannot be neatly categorised as either "female Gothic," or indeed "male Gothic." Hardy reportedly commented to S. M. Ellis after the tale had been published that "a story dealing with the supernatural should never be explained away in the unfortunate manner of Mrs Radcliffe" (Ellis 1928: 398). Here Hardy is acknowledging not only the Gothic as a literary genre, but what he deemed to be one of its faults. Hardy wrote to William Blackwood who published the story, that though it was a "weird" tale, "the cardinal incidents are true, both the women who figure in the story having been known to me" (Purdy and Millgate 1978: 168), 
and viewed as "dull and unimaginative" Stephen's later criticism of there being no scientific explanation provided by Hardy for the "withering" (quoted in Ellis 1928: 397). The "withering" may in fact be read as a physical manifestation of Squire Lodge's tyranny over the female body, a destructive masculinity instrumental in Gertrude's physical and mental decline, resulting in her premature aging and loss of beauty, her "withering." Hardy's lack of a scientific basis for the phenomenon allows for such interpretations. It is a projection of Lodge's toxicity and superficiality, resulting in one woman "dying" twice and the other "falling" twice. Rhoda is punished and ostracised for bearing an illegitimate child, Gertrude is tormented by her loss of beauty and subsequent inability to produce the desired heir. In "The Withered Arm" Hardy presents two contrasting models of masculinity: the benevolent and empathetic Trendle who provides the women with an alternative route to knowledge and understanding, and the malevolent Lodge whose self-obsession destroys them.

In the next tale to be considered, "Barbara of the House of Grebe" (1890), toxic masculinity becomes concentrated into a portrayal of sociopathy, what David Blair describes as "the male project to marginalize or destroy the female mind and will" (2002: xxii). In this tale a husband enjoys mentally torturing his wife to such an extent that she suffers a psychotic breakdown, leaving her ultimately in a similar predicament to her predecessors Rhoda and Gertrude, unable to successfully perpetuate a patrilineal line.

\section{Masculine Maiming in "Barbara of the House of Grebe"}

"Barbara of the House of Grebe" is a lurid tale - Gothic in its composition, it contains elements both gruesome and cruel, and as Susan Hill notes, "it is quite different, in its heartlessness and coldness as well as its Gothic style, from anything else [Hardy] wrote" (1979: 28). James Scott suggests that it is the furthest foray into the Gothic in Hardy's corpus, in which he "assembles nearly all the standard equipment of Gothic grotesquerie: mental imbalance, sexual abnormality, mutilation and disfiguration, sadistic brutality" (1963: 375). Graham Law draws attention to the fact that when A Group of Noble Dames, of which "Barbara" is a part, was published in volume form it created much dissent amongst reviewers, some of whom had previously been supportive of Hardy's work. The Spectator "found a 'nauseous element' pervading every story," while The Saturday Review "wrote off the collection as a "literary freak" (Law 2017: 11). The Pall Mall Gazette attacked the volume as "an abuse of the slackening of "external constraint' concerning sexual matters;" critics were scandalized by the reintroduction into volume form of all of the previously bowdlerized elements from the periodical publication of the stories (Law 2017: 11). As noted above, these elements included "no mention or hint of pregnancy, childbirth, nor sexual relations, whether adulterous or sanctioned by marriage, one or another of which offending incidents occurred in all six tales," though the volume edition in fact contains a total of ten tales (Brownson 2007: 7). Simon Gatrell relates how the original manuscripts show that Hardy cancelled certain passages in blue pencil which were subsequently marked for inclusion in volume form (1988: 83). Such incidents, of course, occur many times throughout Hardy's fictional oeuvre, but one scene contained within "Barbara" was considered to be particularly disturbing - Uplandtowers' mental torture of his wife as his "cure" for her psychological infidelity. Gatrell describes how the first thing to be excised from "Barbara" by the editors of The Graphic was much of the horror that Barbara felt "at the revelation of Edmond's face on his return from Italy; Barbara's terror, Edmond's demand that she look a second time, her shudder at the sight, are all omitted" (1988: 90). And as Gatrell points out, “without experiencing Barbara's extreme distress 
at the frightening aspect of her first husband, it becomes very difficult for the reader to accept the complete transformation in her attitude to her second husband after his "treatment" (1988: 91). This "treatment," or "cure," is the most Gothic element of the story, as will be seen below.

Lord Uplandtowers is Barbara's second husband, after her elopement with the young and handsome Edmond Willowes ends tragically with the latter's death. Edmond had been badly injured during his continental education while risking life and limb rescuing Italian theatre-goers from a fire. When he returns to England, Barbara discovers that most of Edmond's face has been burnt off and he is reduced to wearing a flesh coloured mask. She is unable to control her revulsion, and he flees. Though Uplandtowers is "passionless" and "severe," and seemingly unconcerned at Barbara's inability to feel anything for him, she eventually agrees to marry him after years of fruitless waiting for Edmond's return convince her that the young man is dead (Hardy [1890] 1979: 231). Miserable and alone she fails to provide Uplandtowers with a successor, and he in turn, much like Farmer Lodge with Gertrude after the withering, "asked her what she was good for" (232). When a life-size statue of Edmond arrives, commissioned while he was still an Adonis travelling the continent, Barbara hides it in a specially constructed cupboard and suddenly begins to leave her husband's side each night, only to return after a prolonged period, utterly exhausted and decidedly flushed. The Earl's revenge when he discovers his wife's secret is horrifying. Having obtained a sketch of Edmond's ruined face, he commissions a workman to reproduce the disfigurement of the man upon the statue that had served as a reminder of his former beauty:

What the fire had maimed in the original the chisel maimed in the copy. It was a fiendish disfigurement, ruthlessly carried out, and was rendered still more shocking by being tinted to the hues of life, as life had been after the wreck.

(Hardy [1890] 1979: 237)

When Barbara next visits the statue in the small hours she screams and faints. Uplandtowers has the maimed statue brought to the foot of the marital bed and subjects Barbara to its terrible visage over three consecutive nights, until she is literally horrified out of her longing, both romantic and sexual, for her former husband. Her sadistic new husband laughs brutally at his method of "curing" her (239). Law notes how this entire passage was omitted from the version published in The Graphic; instead "dreading lest the scourge should be applied anew,' she promises to give her love to her current husband" without a single further thought of the first (2017: 23). Widdowson makes the salient point that having Barbara's revulsion at Willowes' disfiguration "significantly lessened," a "sizeable part of her second husband's torturing of her omitted," and the removal of any references to Barbara's "inability to give Lord Uplandtowers a 'lineal successor' and his blaming her for it," all ensure that "much of the ironic animus of the tale" is lost (2013: 374). But Ray makes the most important observation regarding The Graphic's slashing of Hardy's original manuscript, that Uplandtowers is made to appear much more humane, with no mention of his wish for heirs or his demand to know Barbara's gynaecological history (1997: 90). This "morally improved" Uplandtowers does not laugh caustically at his psychological torturing of Barbara; in The Graphic she is only made to look at the mutilated statue once, not over a number of nights, which ultimately causes the schism that renders her an automaton. As 
Ray states, "The new Lord Uplandtowers was no doubt less offensive to Graphic readers, but the story loses much of its Gothic savagery" (1997: 90). ${ }^{6}$

The appearance of statues within Gothic tales is not as prevalent as one might expect. Patricia Merivale posits that "The appearance of a Classical artefact in a Gothic setting suggests some deliberate antithesis" (1974: 960) - the placing of a statue (traditionally a dedication to beauty) into a discourse usually associated with the macabre in order to "polarize [reader] responses, to suggest light in darkness" (960). She goes on to say that the Gothic ethos should be an ideal context in which to feature a statue due to "its role as exemplar of Beauty and Art, those ambiguous enemies of Faith and Life" (960). Yet only a handful of stories from the nineteenth century use this signifier, many preferring the automaton or doll figure. Of the stories that do feature statues, Oscar Wilde's "The Happy Prince" (1888) is a parable of the rich and the poor, while Henry James in "The Last of the Valerii" (1874) has an archaeologist in Rome fall in love with a statue of Juno to such a degree that his wife has the statue reburied. Indeed, in traditional mythology, a malevolent Venus/Dionysus figure comes to life to claim a flesh and blood husband. This trope took a somewhat darker turn with the publication of Edith Nesbit's short story "ManSize in Marble," in the December 1887 number of Home Chimes magazine. It features a pair of statues, Knights who had been men so wicked in life that upon their deaths the great mansion that they had dwelt in was struck by lightning and burned to the ground. Each year on All Saints Eve the statues rise and try to return to their house, and a newly married couple who have moved into a cottage built on the site do not heed warnings to leave, resulting in the violent death of the young wife, whose corpse is found to be gripping in one hand a marble finger. While we cannot be sure that Hardy read this particular tale before writing "Barbara of the House of Grebe," it is certainly worth noting that his is possibly the only other story in which a male statue is the direct cause of a female character's unfortunate end. It is not only a gender reversal of Ovid's Pygmalion of Greek legend, ${ }^{7}$ where a male sculptor falls in love with the female statue he creates, but also a twist on the Jewish Golem myth, in which a male creature is sculpted and brought to life to perform menial tasks, and can only be deactivated by removal of the shem (a symbol of the names of God) on its forehead, at which point it crumbles to dust. As Francesco Marroni notes of "Barbara," "As a fetishistically adored object the work of art obliterates the traumatic image of the 'monster' while at the same time restoring to Barbara the man she longs to remember, making him live again for her eyes only" (1994: 37). The once beautiful Edmond is briefly brought back to life for Barbara, but his task of fulfilling her romantic desires ceases with the destruction of his pleasurableness.

\footnotetext{
${ }^{6}$ Interestingly, when the story first appeared in the US journal Harper's Weekly, no such bowdlerisation took place (Ray 1997: 74). This market may have been more acquiescing to authorial intention due to support of Poe's "unity of effect," espoused decades before, in which "no word or sentence should be included" that does not further the author's intentions in bringing about the exact response wished for in the prospective reader (Killick 2008: 7). A coincidental point made by Ray is that in its original serial publication in both The Graphic and Harper's the story was titled "Barbara, Daughter of Sir John Grebe," but for volume publication its title changed to "Barbara of the House of Grebe," which Ray feels "may be intended to recall Poe's 'The Fall of the House of Usher' and its Gothic apparatus" (1997: 94).

${ }^{7}$ In Ovid's Metamorphosis (1AD) Pygmalion is a sculptor who falls in love with the ivory statue he carves of his own ideal woman. Hearing his prayers, the goddess Aphrodite gives life to the statue, and Pygmalion marries it.
} 
As noted above by Scott, disfigurement is a common feature of the Gothic grotesque. Oscar Wilde utilises this trope to link the Gothic with the Aesthetic in his portrayal of Dorian Gray (1890), a character whose immorality is projected onto a painting secreted in his attic, enabling him to remain youthful and beautiful while the artwork festers in his stead. Dr Jekyll's repressed immorality finds articulation in the grotesque Mr Hyde (1886), a mask for man's innate evil. However, Edmond Willowes is neither immoral nor repressed. In him Hardy represents an instance of virtuous masculinity, a pre-lapsarian Adam figure, "an honest fellow, and the son of an honest father" (Hardy [1890] 1979: 216). It is his nobleness of spirit and sense of duty to his fellow man that results in the disfigurement of his physical beauty, which in turn causes Barbara to recoil in horror. Like Gertrude Lodge before him, Edmond essentially dies twice, corporeally, and then metaphorically, both characters being punished for another's Wildean obsession with aesthetic appearance. Where Gertrude was the unwitting victim of the male gaze, Edmond suffers under the female gaze; upon meeting him Barbara's mother herself openly admires his looks and invites him forward "in no frigid tone:" "How handsome he is! [...] I don't wonder at Barbara's craze for him" (218). Gilmartin and Mengham read this comment in terms of class power, stating that "Barbara and her mother can render the handsome Willowes an object of a sexually appreciative gaze because the power and authority they hold due to their social position and wealth nullifies the more conventional balance of power between men and women" (2016: 62). They go on to say that Barbara's "secret adoration of Edmond's statue would seem to be the final phase in her love for him mainly as a sexual object" (63). Though Barbara is intrinsically naïve, her objectification of Edmond is yet akin to that of the wealthy Farmer Lodge's of Gertrude. The version of "Barbara" included in the volume publication emphasizes that Barbara loved Edmond's physical form over his virtuous character. In this version, as Ray notes, Edmond is described as "plebeian" for the first time, "no doubt to emphasize his social inferiority to Barbara" (1997: 95). Edmond is described as "imperfectly educated," and "his blood of no distinction whatsoever," hence his being sent to the continent with a tutor in order to make him a husband worthy of the Grebe pedigree (Hardy [1890] 1979: 216).

In fact, Brady believes that A Group of Noble Dames is one of Hardy's many attempts, which began with the unpublished novel The Poor Man and the Lady (1868), "to portray the fascination and the difficulty of sexual alliances that cross class boundaries" (1982: 52). The introductory remarks to the volume collection stress that the stories originate in "pages of county histories," and along with his 1891 novel Tess of the d'Urbervilles, the story cycle is "critical of those who romanticize noble lineage" (52). But where the novel is elongated into a saga revolving around the injustices perpetrated by society upon a fallen woman, each story in the cycle A Group of Noble Dames is an interrogation in miniature of class and gender conventions featuring women who are "noble" not just in the material sense, but also in the moral sense, although in the case of "Barbara" the term is applied ironically, considering her failure to appreciate Edmond's virtues and the objectification of him by both Barbara and her mother. Having a collection of stories to compare and contrast better illustrates Hardy's engagement with these themes by presenting them in a format to be read in a single sitting, thus "hold[ing] complete sway over the reader for the duration" (Killick 2008: 7). The Gothic element in "Barbara" is featured in Lord Uplandtowers' subjection of Barbara to the horrific statue while joking and laughing at her obvious distress, an action which is sadistic in the extreme. The mental torture she undergoes eventually causes a psychological schism, leaving her in a state of "obsequious amativeness towards a perverse and cruel man" (Hardy [1890] 1979: 242). Ironically, even after slavishly giving birth eleven times in nine years, Barbara still fails to provide Uplandtowers with an heir. The horror of relentless childbirth and infant death is lost in the bowdlerised Graphic serial version, but restored in its original hideousness for the volume collection. Only one child, a girl, survives childhood. Barbara dies, physically 
and mentally broken, but Uplandtowers does not remarry, and upon his death his title passes to a nephew. Like Lodge before him, Uplandtowers' male line withers, just as Gertrude's arm had done. The cruelty perpetrated by both Lodge and Uplandtowers upon their respective wives ensures that neither are provided with the desired male heir.

The narrator concludes with an indictment of Barbara as "a tender but somewhat shallow lady," who fell in love with Edmond chiefly for his appearance:

the more deplorable in that his beauty, by all tradition, was the least of his recommendations, every report bearing out the inference that he must have been a man of steadfast nature, bright intelligence, and promising life.

(Hardy [1890] 1979: 243).

Gertrude Lodge was also concerned with appearances, confusing lust (this time a husband's) for love: "Six years of marriage, and only a few months of love [...] If I could only again be as I was when he first saw me!" for "Men think so much of personal appearance" (Hardy [1888] 1979: 151, 145). In both these stories Hardy utilises the Gothic tropes of disfigurement, sadism and the grotesque in what could on the surface appear as belonging to the "female Gothic" mode, portraying tyranny over the female, trapping her, and leaving her unable to control access to her space, but unable to escape from it either (Blair 2002: xxii). Yet in "Barbara," it is a male body that is objectified and brutalised, corporeally and metaphorically, through Edmond essentially dying twice in what can be read as a subversion of the female and male Gothic dichotomy. As Wright warns, to read texts in such an essentialist way is reductive. In effect Hardy has set up a dialogue with each "convention" but repudiated neither; instead he acknowledges that the two need not be mutually exclusive, and their amalgamation can in fact work to produce a powerful indictment of toxicity and superficiality with regards to both class and gender. In the last tale to be discussed, the "The Fiddler of the Reels," a woman is punished for her obsession with a demonic fiddle player. Her torment is both mental and physical; but where Gertrude and Barbara were punished by their husbands for their superficiality and supposedly failing in their maternal duties, Car'line Aspent pays for her union with a devil by forfeiting the daughter it produces.

\section{Demonic Masculinity: "The Fiddler of the Reels"}

Hardy felt that a teller of tales must present the reader with "something more unusual to relate than the ordinary experience of every average man and woman," and Mop Ollamoor in "The Fiddler of the Reels" is an uncanny representation of masculine "Othering" (Millgate 1984: 268). Sigmund Freud's concept of das Unheimliche, or the Uncanny, explores that which is eerie and weird, possibly arousing a sense of fear. Freud wrote that there are many opportunities in literature to "achieve uncanny effects that are absent in real life," and thus "better than anyone else, it is the writer who consents to give birth to the Unheimliche" ([1919] 2003: 156). In "The Fiddler of the Reels" Hardy gives birth to the unheimlich Mop Ollamoor, who personifies both the beautiful and the grotesque with his exquisite but infernal fiddle playing. Mop is a demonic fiddler who invades villages and possesses the bodies and souls of young girls through the power of music alone. Without uttering a single word of dialogue throughout the narrative he manages to cause moral breakdown and widespread misery. Physically repellent to, and disliked by, men, he is nonetheless a diabolical siren-like figure, fatally attractive to women. He is first "othered" by "coming from nobody knew where," and then by his "rather un-English," "rich olive" complexion (Hardy [1893] 1979: 287). His hair is described as "rank," "dark" and "rather clammy," to which he applies 
"secret ointments," causing him to smell like "boys'-love" (287). ${ }^{8}$ Mop also at times "wore curls - a double row - running almost horizontally around his head. But as these were sometimes noticeably absent, it was concluded that they were not altogether of Nature's making" (287). Two other characters within Hardy's oeuvre who memorably wear false hair extensions are Felice Charmond in The Woodlanders (1887) and Arabella Donn in Jude the Obscure (1895). Both of these women are anti-heroines, or femmes fatales, whose male admirers consequently suffer pain and even death. ${ }^{9}$ Identifying Mop with the figure of the femme fatale, and then having him employ supernatural means of seduction through his fiddle-playing, connects him to Lucifer, the most beautiful of angels who directed the flow of music in heaven, but who was cast out for daring to challenge the rule of God. Mop appears to be an extension of Hardy's earlier androgynous villains - Anaeas Manston from his first published novel Desperate Remedies (1871), and Will Dare in A Loadicean (1881). While Manston is "extremely handsome" and his "manner is elegant," his face is "rather too delicately beautiful," and his character shows a "dangerous effeminacy" (Hardy [1871] 2003: 131). Like Mop after him, "the effect of [Manston's] form and features upon womankind en masse" is formidable (157). Like Mop, Will Dare also sports a feminine appearance, wearing his hair parted in the middle, "hung as a fringe or valance above, in the fashion sometimes affected by the other sex," yet there is "a swagger in his body and limbs [...] a latent power" (Hardy [1881] 1997: 45). Following on from Manston and Dare, Hardy has represented Mop's masculinity as being dangerous precisely for its feminine qualities. Mop Ollamoor's unheimlich beauty is rendered grotesque via his "fantastical bowing" of "devil's tunes," a delineation linking him with the Gothic aestheticism of Wilde's character Dorian Gray (Hardy [1893] 1979: 288).

Hardy's narrator compares Mop to Niccolo Paganini (287), the early nineteenthcentury Italian musician and composer known as "The Devil's Violinist," who, almost certainly apocryphally, proclaimed: "I am not handsome, but when women hear me play, they come crawling to my feet." And just as it is said that audiences spontaneously burst into tears at the enchanting ferocity of Paganini's violin-playing, so Mop Ollamoor can "make any child in the parish [...] burst into tears in a few minutes" ([1893] 1979: 287). Like Will Dare before him, Mop is, according to Brady, linked with Dionysus, though rather than his looks, it is with rites that use dance and music as intoxicants to remove inhibitive societal constraints. Brady also links Mop with Orpheus and Eros, claiming that he is a "quasi-mythical figure," whose physical and psychic potency is "inseparable from his music" (1982: 135). This again recalls Aeneas Manston, whose organ playing during an electrical storm so enthrals Cytherea that the music he plays "enters into her with a gnawing thrill," causing her to "shrink up beside him and look with parted lips at his face" (Hardy [1871] 2003: 132). Mop's bowing is "fantastical," and all "were devil's tunes in his repertory" (Hardy [1893] 1979: 288). From the moment Car'line Aspent first hears his "insidious" notes she is "compelled" (289). Simply walking past him for the first time becomes an uncontrollable "caper" (289), reminiscent of St. Vitus's Dance, or the Tarantella performed by Nora in Ibsen's A Doll's

\footnotetext{
${ }^{8}$ Hardy's choice of flower here is telling. Artemisia Abrotanum, or "boy's-love," is also commonly known as "maiden's-ruin," "maid's-love" and "maid's-passion." See https://www.rhs.org.uk/Plants/ 1624/i-artemisia-abrotanum-i/Details.

${ }^{9}$ In The Woodlanders, Felice charms an unnamed American-Italian suitor who shoots himself after fruitlessly following her across Europe. She also has an affair with Edred Fitzpiers; when the father of Edred's wife Grace Melbury discovers this, the latter physically assaults Fitzpiers, leaving him bleeding and requiring medical attention. Arabella Donn adorns herself with fake curls in her notorious seduction of Jude Fawley. He ultimately suffers for his folly, losing the woman he truly loves - Sue Bridehead - and dying miserable and alone.
} 
House. Such is Mop's malevolent enchantment of Car'line that she will without warning start from her chair "as if she had received a galvanic shock, and spring convulsively toward the ceiling; then she would burst into tears" (298). This is in response to simply hearing Mop's footsteps pass by the window. Mop is said to be "able to play the fiddle so as to draw your soul out of your body like a spider's thread ... till you felt as limp as withywind and yearned for something to cling to" (290). Hardy's use of language such as "fantastical," "compelled" and "shocked" are all reminiscent of the Gothic's protegee - the Sensation novel or tale. Just as Nemesvari categorises Desperate Remedies as a sensation novel, "Fiddler" can, according to Nemesvari's checklist, be accorded the epithet of sensation tale, containing as it does the "structural staples of melodrama as tableaux and sensation scenes" (Nemesvari 2011: 5). Car'line's entrancements while Mop fiddles are tableaux of torture, with Mop appearing as a "fiddling figure against the wall." Car'line is "seized" into dancing and writhing until her feet ache, "convulsively dancing on," Mop's music "projecting through her nerves excruciating spasms" (Hardy [1893] 1979: 299-300). Brady notes that "As a man and as a symbol," Mop is "a sexual force which can move women to act irresponsibly, and in a manner destructive not only of their own independence but also of the order of society as a whole" (Brady 1982: 135). This is similar to Charlotte Dacre's Zofloya, where the Moor can move Victoria to act irresponsibly in such a way that her dependence upon him becomes destructive not just for her but for her victims. Likewise, Matthew Lewis's Matilda moves Ambrosio in The Monk to act in ways that destroy all around him, including himself. But where Dacre and Lewis have the narrative space of a novel to demonstrate the many perversions perpetrated by their villains on numerous victims, the brevity of the short story form allows Hardy to showcase a particular example of corruption and its lasting legacy. Even while the narrator of "Fiddler" tries to employ a discourse of scientific rationalism in explaining Car'line's actions as certain automatic neurological responses, Hardy invests Mop with an aura of supernaturalism and raw sexual energy through his descriptions of the unearthly and uncanny exuberance of Mop's fiddle-playing. As Andrew Radford points out, Hardy seems to suggest that "even in a scientific age, the irrational and folkloric remains a persistent threat to social order" (1999: 77).

Carol Senf reads "The Fiddler of the Reels" as Hardy incorporating Gothic tropes without the story itself actually being Gothic (Senf 2017: 1). But when we consider the three elements mentioned by James Scott above - the preternatural, the terrible, and the grotesque - we find each equally represented in a folkloric tale which explores sexual taboos and the subjection of a female character to bodily tyranny, and the destruction of the female mind and will. However, while it is Car'line Aspent's body which is tyrannised, it is Ned Hipcroft's spirit that is broken. Car'line's "manly and simple wooer" is in effect thwarted twice in his suit (Hardy [1893] 1979: 290). After his initial rejection by Car'line in favour of Mop, Ned removes himself to London to find work as a labourer, but he also tends to himself "with the facility of a woman" by cooking, cleaning and even darning his own "stocking-heels" (291). Ned is, according to Brady, sexually indifferent, and "seriously lacking in sexual energy," a perfect foil to Mop's raw sexual potency (1982: 137). Hardy has endowed both Ned and Mop with a masculinity that is somewhat feminine in its portrayal. Mop's feminine accoutrements are supplemented by his unheimlich qualities, making him irresistible to the female sex. Ned's soundness, placidity and womanly facilities ensure that he is the punished party for the transgressions of another, just as Gertrude Lodge before him is ultimately punished for the previous transgressions of her callow and superficial husband. Ned is not the victim of toxicity, however, but rather of female apathy and non-maternalism. He is quick to adopt a paternal role and grows to love Car'line's daughter (the product of Car'line's unholy union with Mop) as his own. The daughter is referred to as Little Carry, although Car'line as mother never directly addresses her in the narrative. 
Many of Hardy's stories, even more prevalently than the novels, undermine the notion that motherhood fulfils a woman's needs. This is one of the underlying themes of the story cycle A Group of Noble Dames, featuring "Barbara." But when Car'line's daughter is whisked away by Mop, in the words of Gilmartin and Mengham, Car'line "literally loses no sleep" over the abduction, "while the child's adoptive father lies awake full of terrible imaginings" (2016: 74). Ned's passionate proclamations after the little girl's disappearance further link him to the feminine: "But she is mine, all the same! Ha'n't I nussed her? Ha'n't I fed her and teached her? Ha'n't I played wi' her? O, little Carry - gone with that rogue gone!" (Hardy [1893] 1979: 303). In stark contrast to this Car'line "peevishly" scolds Ned: "Don't 'ee raft yourself so, Ned! You prevent my getting a bit o' rest!" (304). In "Candour in English Fiction" Hardy noted that "it will be conceded by most friends of literature that all fiction should not be shackled by conventions concerning budding womanhood, which may be altogether false" (Hardy, quoted in Orel 1966: 131). Car'line anticipates one who is perhaps Hardy's most reviled female character, Arabella Donn, Jude Fawley's first wife in Jude the Obscure (1894). Where Arabella was likened by Margaret Oliphant to a human pig (1896: 139), Ray describes Car'line as an "increasingly selfish and self-pitying" girl, in opposition to Ned who bewails the loss of a child not his own (1997: 222). Interestingly it appears that over the many revised versions of "Fiddler," Mop and Car'line become distinctly more unpleasant in parallel with Ned becoming increasingly selfless and devoted to little Carry. In the serial version published in Scribner's Magazine in New York, Mop is described as "tolerable," but in the first collected edition, Life's Little Ironies of 1894, and then in the Wessex edition of Hardy's entire oeuvre of 1912, Mop becomes "repulsive" (Ray 1997: 224). Correspondingly a "harsher and more critical portrait of Car'line progressively emerges," and Ned's instant rapport with little Carry is strengthened (224-5).

Hardy uses Mop's repulsiveness and Ned's maternal nurturing of a child not his own as an indictment of contemporary societal constraints of masculinity and its various forms of articulation. Mop's incorporation of femininity problematises readings of him as a lothario, but it also serves to draw attention to Ned's problematic masculinity. While on the one hand Ned's womanly traits indicate practicality and self-sufficiency, on the other his feminine qualities lead him to be compromised when Mop abducts Little Carry at the end of the story. He is ultimately unable to protect his lover and his daughter by proxy from the demon fiddler. Hardy also wished to challenge heteronormative notions of femininity by portraying Car'line as a distinctly unmaternal woman whose physical responses to the "Devil's violinist" belie the conventions expected of her kind. As Richard Nemesvari notes, "A cultural ideology that attempted to construct most women, or at least most 'proper' women, as asexual domestic angels was profoundly shaken by the suggestion that female passion and sensuality were pervasively present," as they are in both "Barbara of the House of Grebe" and "Fiddler of the Reels" (2011: 11). And by pointing out in "Candour in English Fiction" that literature should not be shackled by conventions concerning womanhood, Hardy is stressing that maternity and its associated functions and roles are social constructs, not factors inextricably linked to gender.

\section{Conclusion}

Gothic masculinity as presented in these three stories is one that at first suggests toxicity, but is complicated by dichotomies of benevolence and malevolence, and problematised by incorporation of the feminine. In "The Withered Arm" Hardy presents two contrasting models of masculinity: the empathetic Conjuror Trendle who provides Gertrude Lodge and Rhoda Brook with an alternative route to knowledge and understanding via folkloric traditions, and the malevolent Farmer Lodge whose self-obsession destroys the two women. 
In "Barbara of the House of Grebe" it is a male, rather than a female, body that is objectified and brutalised, corporeally and metaphorically. Edmond Willowes essentially dies twice in what can be read as a subversion of the reductive concept of female and male Gothic. And where Car'line may be read as paying for her union with a devil and subsequent lack of maternal instinct by forfeiting the daughter it produces in "Fiddler of the Reels," it is Ned Hipcroft, the girl's father by proxy, who is punished, twice, and each time by a diabolical mirror image of his femininely masculine self. Via the format of the short story, Hardy is able to delineate the inherent perversity of human nature in a circumscribed and thus more concentrated form than he could over the course of a realist novel. He appropriates certain aspects of the Gothic which foreground terror and psychological torment in these tales of a deformed limb, a mutilated statue and a Satanic fiddle player, and refuses to offer a rational explanation for the supernatural events that take place within each text. Hardy's liberation of tropes from folklorist narratives such as that of the "cunning man" in "The Withered Arm" provides a means of repossessing imaginative territories which are successfully combined with those of the Gothic to create instances of the otherwise marvellous and incredible. Taboos such as (implied) sexual relations with a statue or an other-worldly musician are transgressed through the appropriation of Gothic conventions such as imprisonment and torture. And by anticipating Freud's theory of das Unheimliche, Hardy invokes the Gothic in order to subvert what is knowable and controllable. The short story form is the perfect vehicle for Hardy's tales that are more than "exceptional enough to justify their telling" (Millgate 1984: 268).

\section{Bibliography}

“Artemisia abrotanum / southernwood." RHS. https://www.rhs.org.uk/Plants/1624/i-artemisiaabrotanum-i/Details

Björk, Lennart A., ed. 1985. The Literary Notebooks of Thomas Hardy, Volume One. New York: New York University Press.

Blair, David, ed. 2002. Gothic Short Stories. Hertfordshire: Wordsworth Edition.

Brady, Kristin. 1982. The Short Stories of Thomas Hardy. Basingstoke: Macmillan. DOI: https://doi.org/10.1007/978-1-349-07402-0

Brownson, Siobhan Craft. 2007. "“A Group of Noble Dames' and the Short Story Cycle." CEA Critic, 70, no.1: 1-16.

Clery, Emma. 1995. The Rise of Supernatural Fiction, 1762-1800. Cambridge: Cambridge University Press.

Dacre, Charlotte. ([1806] 2008). Zofloya; or, The Moor: A Romance of the Fifteenth Century, edited with an introduction by Kim Ian Michasiw. Oxford: Oxford University Press.

Dillion, Jacqueline. 2016. Thomas Hardy: Folklore and Resistance. Basingstoke: Palgrave Macmillan. DOI: https://doi.org/10.1057/978-1-137-50320-6

Ellis, S. M. 1928. “Thomas Hardy: Some Personal Recollections.” Fortnightly Review, n.s. 123: 393-406.

Firor, Ruth A. 1962. Folkways in Thomas Hardy. New York: Perpetua Books.

Freud, Sigmund. 2003 [1919]. The Uncanny, trans. David McLintock. Harmondsworth: Penguin. 
Gatrell, Simon. 1993. Thomas Hardy and the Proper Study of Mankind. Charlottesville: University Press of Virginia.

Gatrell, Simon. 1988. Hardy the Creator: A Textual Biography. Oxford: Oxford University Press.

Gilmartin, Sophie and Rod Mengham. 2016. Thomas Hardy's Shorter Fiction: A Critical Study. Edinburgh: Edinburgh University Press.

Gilmartin, Sophie. 2013. "Hardy and the Short Story." In Thomas Hardy in Context, edited by Phillip Mallett, 132-42. Cambridge: Cambridge University Press. DOI: https://doi.org/ 10.1017/CBO9781139048095.018

Hardy, Thomas. [1871] 2003. Desperate Remedies, edited with an introduction by Patricia Ingham. Oxford: Oxford University Press.

Hardy, Thomas. [1879] 1979. The Distracted Preacher and Other Tales, edited with an introduction by Susan Hill. Harmondsworth: Penguin.

Hardy, Thomas. [1881] 1997. A Laodicean, edited with an introduction by John Schad. Harmondsworth: Penguin.

Hardy, Thomas. [1886] 2004. The Mayor of Casterbridge, edited with notes by Dale Kramer, introduction by Pamela Dalziel. Oxford: Oxford University Press.

Hardy, Thomas. [1887] 2005. The Woodlanders, edited with notes by Dale Kramer, introduction by Penny Boumelha. Oxford: Oxford University Press.

Hardy, Thomas. [1888] 1979. "The Withered Arm." In The Distracted Preacher and Other Tales, edited with an introduction by Susan Hill. Harmondsworth: Penguin, 134-64.

Hardy, Thomas. [1890] 1979. "Barbara of the House of Grebe." In The Distracted Preacher and Other Tales, edited with an introduction by Susan Hill. Harmondsworth: Penguin, 211-43.

Hardy, Thomas. [1893] 1979. "The Fiddler of the Reels." In The Distracted Preacher and Other Tales, edited with an introduction by Susan Hill. Harmondsworth: Penguin, 286-304.

Hervoche-Bertho, Brigitte. 2001. "Seminal Gothic Dissemination in Hardy's Writings." Victorian Literature and Culture, 29.2: 451-67. DOI: https://doi.org/10.1017/S106015030100211X

Killick, Tim. 2008. British Short Fiction in the Early Nineteenth Century: The Rise of the Tale. Burlington: Ashgate. DOI: https://doi.org/10.4324/9781315570297

Law, Graham. 2017. "Neither Tales nor Short Stories?: Issues of Authorship, Readership, and Publishing in A Group of Noble Dames." In Thomas Hardy's Short Stories, edited by Juliette Berning Schaefer and Siobhan Craft Brownson, 11-30. Abingdon: Routledge.

Lawrence, D. H. [1914] 1998. D. H. Lawrence: Selected Critical Writings, edited with an introduction and notes by Michael Herbert, Oxford: Oxford University Press.

Lea, Hermann. [1913] 1969. Thomas Hardy's Wessex. Basingstoke: Macmillan.

Lewis, Matthew Gregory. [1796] 2008. The Monk: A Romance, edited with an introduction by Emma McAvoy. Oxford: Oxford University Press.

Marroni, Francesco. 1994. "The Negation of Eros in 'Barbara of the House of Grebe." Thomas Hardy Journal, 10.1: 33-41.

Merivale, Patricia. 1974. "The Raven and the Bust of Pallas: Classical Artefacts and the Gothic Tale." PMLA, 89.5: 960-66. DOI: https://doi.org/10.2307/461369

Millgate, Michael. 2004. Thomas Hardy: A Biography Revisited. Oxford: Oxford University Press.

Millgate, Michael, ed. 1984. The Life and Work of Thomas Hardy by Thomas Hardy. Basingstoke: Macmillan. DOI: https://doi.org/10.1007/978-1-349-10117-7

Mitchell, Judith. 2010. "Hardy and Gender." In Ashgate Research Companion to Thomas Hardy, edited by Rosemarie Morgan, 301-14. Burlington: Ashgate. DOI: https://doi.org/ $10.4324 / 9781315613680$ 
Nemesvari, Richard. 2013. “'Genres are not to be mixed...I will not mix them': Discourse, Ideology, and Generic Hybridity in Hardy's Fiction." In A Companion to Thomas Hardy, edited by Keith Wilson, 102-16. Oxford: Blackwell Publishing. DOI: https://doi.org/10.1002/ 9781444324211.ch7

Nemesvari, Richard. 2011. Thomas Hardy, Sensationalism, and the Melodramatic Mode. Basingstoke: Palgrave Macmillan. DOI: https://doi.org/10.1057/9780230118843

Oliphant, Margaret. 1896. “The Anti-Marriage League.” Blackwood's Magazine, 158 (January): $135-49$.

Orel, Harold, ed. 1966. Thomas Hardy's Personal Writings: Prefaces, Literary Opinions, Reminiscences. Lawrence: University of Kansas Press.

Purdy, Richard Little and Michael Millgate, eds. 1978. The Collected Letters of Thomas Hardy Volume One: 1840-1892. Oxford: Clarendon Press.

Radford, Andrew. 1999. “Thomas Hardy's 'The Fiddler of the Reels' and Musical Folklore.” Thomas Hardy Journal, 15. 2: 72-81.

Ray, Martin. 1997. Thomas Hardy: A Textual Study of the Short Stories. Abingdon: Routledge.

Scott, James F. 1963. "Thomas Hardy's Use of the Gothic: An Examination of Five Representative Works." Nineteenth-Century Fiction, 17. 4: 363-80. DOI: https://doi.org/10.2307/2932631

Senf, Carol. 2017. "Realism, horror and the Gothic in Dracula and Thomas Hardy's 'The Fiddler of the Reels"." Palgrave Communications, www.nature.com/palcomms.2017.83

Udal, John Symonds. 1922. Dorsetshire Folk-Lore. Devon: Dorset Books.

Whitehead, Stephen. 2002. Men and Masculinities. Cambridge: Polity Press.

Widdowson, Peter. 2013. ““...into the hands of pure-minded English girls': Hardy's Short Stories and the Late Victorian Literary Marketplace." In A Companion to Thomas Hardy, edited by Keith Wilson, 364-77. Oxford: Blackwell Publishing. DOI: https://doi.org/10.1002/ 9781444324211.ch24

Wright, Angela. 2007. Gothic Fiction: A Reader's Guide to Essential Criticism. Basingstoke: Macmillan. 